\title{
CARDIAC COMPLICATIONS IN PATIENTS INFECTED WITH COVID-19
}

\author{
Maria Magdalena Leon-Constantin, Alexandra Maștaleru, Irina Mihaela Abdulan, \\ Mădălina Ioana Zota, Sabina Cojocariu, Florin Mitu \\ "Grigore T Popa" University of Medicine and Pharmacy, Iași \\ Corresponding author: \\ Alexandra Maștaleru \\ E-mail: alexandra.mastaleru@gmail.com
}

\begin{abstract}
Cardiovascular disease remains the leading cause of death and morbidity worldwide. The appearance of the pandemic with COVID-19 at the beginning of this year all over the world makes the approach of the patients different. SARS-CoV-2 has major implications for the cardiovascular system. In addition to acute complications, COVID-19 infection can predispose to cardiovascular disease. Recent data show that myocarditis occurs in some patients with COVID-19, a few days after the onset of fever. This indicates the possibility of viral nature of myocardial lesions. In addition, patients infected with COVID-19 may be tachycardic (with or without palpitations) in relation to other symptoms related to the disease (fever, tachypnea, pain). They noticed several particular aspects, including rhythm disorders.

It is known that in patients with pneumonia, hypercoagulability and systemic inflammatory activity may persist for a long time. This explains the occurrence of arterial and venous thrombotic complications in acute coronary syndromes or venous thromboembolism. The latest guideline for the diagnosis and management of cardiovascular disease during the COVID-19 pandemic states that, although there is no solid evidence to date, the incidence of pulmonary thromboembolism in infected patients is high, thus recommending prophylactic doses of anticoagulant. The COVID-19 pandemic has affected millions of patients and poses an international health threat and considerable efforts are currently being made to evaluate new therapies to counteract this virus.
\end{abstract}

Keywords: pandemic, SARS-CoV-2, cardiovasculardisease.

\section{Rezumat}

Bolile cardiovasculare rămân principala cauză de mortalitate și morbiditate la nivel mondial. Apariția pandemiei cu COVID-19 la începutul acestui an în întreaga lume face ca abordarea pacienților să fie diferită. SARS-CoV-2 determină implicații majore asupra sistemului cardiovascular. Pe lângă complicații acute, infecția cu COVID-19 poate predispune la apariția unor boli cardiovasculare. Date recente arată că miocardita apare la unii pacienți cu COVID- 


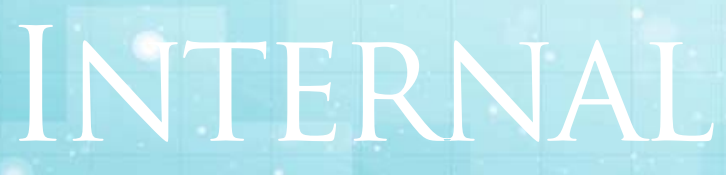

\section{General Reviews}

19, la câteva zile de la debutul febrei. Aceasta indică posibilitatea naturii virale a leziunilor miocardice. În plus, pacienții infectați cu COVID-19 pot fi tahicardici (cu sau fără palpitații) în relație cu alte simptome legate de boală (febră, tahipnee, durere). La aceștia s-au observat mai multe aspecte particulare, printre care și tulburările de ritm.

Este cunoscut faptul că la pacienții cu pneumonie, starea de hipercoagulabilitate și activitatea inflamatorie sistemică pot persista o perioadă lungă de timp. Astfel se explică apariția complicațiilor trombotice arteriale și venoase din cadrul sindroamelor coronariene acute sau tromboembolismului venos. Ultimul ghid de diagnostic și management al bolilor cardiovasculare în timpul pandemiei de COVID-19 susține că, deși până în prezent nu există dovezi solide, incidența trombembolismului pulmonar la pacienții infectați este ridicată, recomandându-se astfel doze profilactice de anticoagulant.

Pandemia COVID-19 a afectat milioane de pacienți și reprezintă o amenințare la adresa sănătății la nivel internațional, depunându-se la momentul actual eforturi considerabile pentru evaluarea noilor terapii de contracarare a acestui virus.

Cuvinte cheie: pandemie, SARS-CoV-2, boli cardiovasculare

\section{Introduction}

Cardiovascular diseases remain the leading cause of death and morbidity worldwide. The appearance of the pandemic with COVID-19 at the beginning of this year all over the world makes the approach of the patients different. On the one hand, the population is asked to remain in isolation and there is a risk of insufficient treatment of the underlying heart disease, and on the other hand, it is known that cardiovascular complications may occur during SARS-2 infection. Regarding the impact of SARS-2 on the general population, the data published by the National Institute of Public Health indicates that by 19 July, 13:00, 37,458 COVID-19 cases were registered in Romania. Of the people confirmed positive, 25,042 were discharged, of which 22,617 patients recovered and 2,425 asymptomatic patients, discharged 10 days after the detection. Up to this date 2,026 people diagnosed with COVID19 infection have died. Globally 14,007,791 cases and 597,105 deaths were registered $^{(1)}$. It remains to be seen whether the cardiac decompensation was the cause of deaths.

Thereby, recent data show that the clinical manifestations of COVID-19 patients are 
diverse. A study conducted in China on 72,314 COVID-19 positive individuals, regarding the intensity of the disease, reveals moderate clinical severity in $81.4 \%$ of the cases, severe in $13.9 \%$ and critical in $4.7 \%{ }^{(2)}$. The clinical symptomatology of moderate severity infection was similar to any viral infection: fever, cough, dyspnoea, myalgia, fatigue and diarrhoea. In severe cases of COVID-19, pneumonia, acute respiratory distress syndrome and cardiogenic shock may be present. Patients with the most severe clinical presentation had the highest mortality rate ${ }^{(3,4)}$. This viral infection, however, also has a direct effect on the cardiovascular system, and preexisting conditions in this area play an important role in the evolution of COVID-19 infection. All these patients are at a higher risk of getting sick, and the infection itself is associated with cardiovascular complications $^{(5-7)}$.

\section{COVID-19 infection and cardiovascular pathology}

SARS-CoV-2 has major implications for the cardiovascular system. Patients with cardiovascular risk factors such as male gender, older age, diabetes mellitus, hypertension and obesity, as well as patients with a history of cardiac or cerebrovascular diseases are considered particularly vulnerable, with increased morbidity and mortality ${ }^{(8)}$. Furthermore, some patients may develop cardiac injuries in the context of COVID-19, leading to an increased risk of inpatient mortality ${ }^{(3)}$.

In addition to acute complications, COVID-19 infection can predispose to some cardiovascular diseases (CVD). It is known that in patients with pneumonia, hypercoagulability and systemic inflammatory activity may persist for a long time. This explains the occurrence of arterial and venous thrombotic complications in acute coronary syndromes or venous thromboembolism. The long term effects of a COVID-19 infection are not entirely known, but the stated elements justify the supervision of recovered patients.

\section{Pathophysiological mechanisms}

The pathophysiology of the COVID-19 infection explains the way the virus is binding to the angiotensin-converting enzyme receptor of the host, to mediate entering the cells. Associated CVD probably involves the activation of the renin-angiotensin system/ angiotensinconverting enzyme 2 due to SARS-CoV-2 infection. COVID-19 is first of all a respiratory illness, but many patients also have CVD. This may be secondary to lung disease, as acute lung injury itself raises cardiac workload and may be a problem especially in patients with pre-existing heart failure. CVD may also be a primary phenomenon, given the important role of the renin-angiotensin system/ angiotensinconverting enzyme 2 in the CV system and the fact that ACE2 is expressed in heart, vascular cells and pericytes ${ }^{(9)}$.

The presence of pre-existing hypertension appears to be higher in patients with COVID-19 who develop severe form of disease ${ }^{(10,11)}$. This may also be valid for acute respiratory distress syndrome or death. However, the results of these studies were not correlated with age.

These assumptions are based on some experimental discoveries according to which the RAS inhibitors cause a compensatory increase of ACE tissue level and ACEI or angiotensin receptor blockers may be harmful in patients exposed to SARS-CoV-2. However, it is important to point out that there is no clear evidence that the use of ACEI or angiotensin receptor blockers is harmful. The data available from blood samples suggest that there is no 


\section{INTERNAI}

\section{General Reviews}

correlation between ACE2 circulating levels and the use of RAAS antagonists ${ }^{(12)}$. It also seems that in experimental models angiotensin receptor blockers may have a potentially protective influence ${ }^{(13)}$. This is in concordance with the recommendations of the main cardiology societies, which stated that patients with angiotensin receptor blockers in their chronic treatment scheme should not stop treatment ${ }^{(12,14)}$.

\section{Myocarditis, myocardial lesions and acute coronary syndrome}

Recent data show that myocarditis occurs in some patients with COVID-19, a few days after the onset of fever. This indicates the possibility of viral nature of myocardial lesions. The mechanisms for producing SARS-CoV-2induced injury may be related to changes in ACE2 at cardiac or vascular level ${ }^{(14,15)}$.

Respiratory failure and hypoxia in COVID-19 may also cause myocardial damage. Immunological mechanisms in myocardial inflammation play an important role ${ }^{(14-16)}$. For example, the cardiac injury leads to the activation of innate immune response, with proinflammatory cytokine release, as well as to the activation of autoimmune-type adaptive mechanisms via molecular mimicry.

Myocarditis, identified by elevated troponin levels ${ }^{(12,13,17,18)}$, was present in a large proportion of patients infected with COVID-19, with significant differences between those who died and those who recovered ${ }^{(4,19)}$. In a metaanalysis involving a total of 341 patients, a significantly higher average value of cardiac troponin I was noticed in all those with severe forms of COVID-19 compared to those with milder forms of the disease $(25.6,95 \% \mathrm{Cl} 6.8$ $44.5)^{(20)}$. Myocarditis also plays an important role in the evolution of patients with acute heart failure. They also had electrocardiographic and echocardiographic changes, which were associated with the severity of the infection and negative prognosis.

An issue worth mentioning is that elevated cardiac troponin levels are not specific and do not allow the causes of myocardial lesions to be determined. In COVID-19 patients, elevated levels are present in myocarditis (which may have an AMI-like presentation with normal coronary arteries ${ }^{(5,6)}$, hypoxic injury, stress cardiomyopathy, ischemic lesion caused by microvascular cardiac lesions and SIRS.

Although the predominant symptomatology of COVID-19 is respiratory, a clinical case in Italy has been described where the patient presented with angina-like pain and electrocardiographic changes for which cardiac catheterization was performed. To be noted that the patient did not have any coronary artery obstruction, instead he was found COVID-19 positive ${ }^{(21)}$.

A case report described a 21 year old female patient with COVID-19 presenting regional 
wall motion abnormalities. The endomyocardial biopsy reveals the presence of lymphocytic myocarditis, but the molecular analysis showed the absence of SARS-CoV-2 genome in the myocardium ${ }^{(22)}$. Another report described a patient infected with COVID-19 who developed cardiogenic shock. Electronic microscopy of endomyocardial biopsy fragments revealed low-grade interstitial and endocardial inflammations, with viral particles identified in the macrophages, but not in the cardiomyocytes, which presented nonspecific characteristics (focal myofibrillar lysis and lipid droplets) ${ }^{(23)}$. These cases illustrate that the identification of the virus from upper or lower respiratory tract is not enough to prove that the myocardial lesion was caused by the viral infection.

The evidence that the COVID-19 virus may be a new cause of viral myocarditis requires the presence of histological findings (inflammatory lymphomonocytic infiltrations accompanied by myocyte necrosis, which is not typical of ischemic lesions), and the identification of COVID-19 genome in the heart tissue and/or identification of viral particles in cardiomyocytes in the absence of known cardiotropic viruses ${ }^{(24)}$.

\section{Rhythm disorders}

Although patients infected with COVID-19 may be tahycardic (with or without palpitations), in connection with other disease related symptoms (fever, tachypnea, pain), several particular aspects worth mentioning have been noticed. In a cohort in Hubei province, $7.3 \%$ of the COVID positive patients who addressed the emergency room reported palpitations as a primary symptom ${ }^{(25)}$. In a group of 393 patients infected with COVID-19 from New York, supraventricular arrhythmias were more common in patients needing mechanical ventilation $(17.7 \% \text { vs. } 1.9 \%)^{(26)}$. There were other categories of patients who were observed to have rhythm disorders, regardless of the presence of pre-existing cardiovascular disease: those with myocarditis or signs of myocardial ischemia at the onset of the infection, patients who developed hypoxic phenomena, (septic or cardiogenic) shock or SIRS, those with hyperkalemia or patients with fever (Brugada syndrome and long QT syndrome) $)^{(27)}$.

Furthermore, this wide range of arrhythmias that complicate the evolution of COVID-19 can also be explained by the potential proarrhythmic effects of the treatment.

\section{Heart failure}

Limited data is available about the incidence of heart failure in patients with COVID-19. The condition may be triggered either by acute noncardiac events in patients with chronic diseases (coronary disease, hypertension), or by acute events (acute myocardial infarction, stress cardiomyopathy, SIRS). Thereby, patients with known history of heart failure may have an episode of decompensation caused by COVID-19 infection ${ }^{(28)}$.

In a retrospective study including 799 patients from Wuhan, admitted with COVID-19, heart failure was identified as a complication in $49 \%$ of the patients who died and only in $3 \%$ of the patients who recovered, despite of a prevalence lower than $1 \%$ of chronic heart failure in the combined groups ${ }^{(29)}$. In another study conducted on 191 patients admitted in two medical centres in Wuhan, heart failure was identified in $52 \%$ of the patients who died and in $12 \%$ of the patients who recovered ${ }^{(30)}$.

Acute heart failure incidence has not been documented in some patient series admitted with COVID-19, but increased levels of the natriuretic peptide (BNP and NT-proBNP) have 


\section{INTERNAL}

\section{General Reviews}

been identified. Another recent analysis showed that NT-proBNP levels were significantly higher in patients with elevated troponin levels than in patients without changes in the cardiac enzymes (1689 vs. 139 $\mathrm{pg} / \mathrm{mL})^{(31)}$.

\section{Pulmonary thromboembolism (PTE)}

The latest guideline for the diagnosis and management of CVD during the COVID-19 pandemic states that, although there is no solid evidence to date, the incidence of PTE in infected patients is high ${ }^{(32,33)}$. Taking into account this recommendation, as well as the presence of systemic inflammation associated with COVID-19, the existence of hypoxemia and prolonged immobilization, anticoagulation in standard prophylactic doses should be considered for all patients confirmed with COVID-19, hospitalized.

Infected individuals often experience respiratory symptoms and may also report chest pain and hemoptysis ${ }^{(34)}$. The mentioned symptoms largely overlap with the signs of PTE, which may lead to underdiagnosing of embolism. Thereby, it is recommended taking into account the PTE diagnosis in patients with COVID-19 infection presenting worsening dyspnoea, a new onset tachycardia, lowered BP that is not attributed to tachyarrhythmia, hypovolemia or sepsis, ECG changes suggestive for PTE, and signs of deep vein thrombosis of extremities. The specificity of Ddimer may be lower in patients infected with COVID-19 compared to other pathologies, however the guideline recommends the use of the diagnostic algorithms (pre-test probability and D-dimer testing, especially when pre-test probability dependent on the D-dimer value is used). Once the PTE diagnosis is confirmed, the treatment should be guided according to the current ESC recommendations.

To be noted that some of the drugs used in COVID-19 infection treatment may have significant interactions with NOAC. This may be the case of the lopinavir/ritonavir combination, which inhibits the action of cytochrome P450 3A4 (CYP3A4) and/or of P-glycoprotein (P-gp). In such cases, the risk of bleeding may be high and NOAC should be avoided. Since close monitoring is required, the use of vitamin $K$ antagonists (VKA) should only be considered in special circumstances, such as the presence of mechanical heart valve prostheses or antiphospholipid syndrome ${ }^{(35)}$.

\section{Conclusions}

The COVID-19 pandemic has affected millions of patients and poses an international health threat. In the future, considerable efforts will be made to evaluate new therapies to counteract this virus. There are theories regarding the increased severity of the disease in patients with cardiovascular comorbidities. 
However, thorough investigation, including histological examination of cardiac tissue in patients with COVID-19, is necessary to define the relationship between the presence of the virus and myocardial lesion. Since biopsyproven myocarditis may occur in the absence of troponin release, studies including autopsy data of COVID-19 victims, regardless of troponin levels, would be useful in clarifying whether or not the COVID-19 is a new cause of viral myocarditis.

\section{References}

1. Centrul Național de Supraveghere şi Control al Bolilor Transmisibile https://www.cnscbt.ro/index.php/situatiala-nivel-global-actualizata-zilnic

2. Wu Z, McGoogan JM. Characteristics of and Important Lessons From the Coronavirus Disease 2019 (COVID-19) Outbreak in China: Summary of a Report of 72314 Cases From the Chinese Center for Disease Control and Prevention. JAMA Feb 24. doi: 10.1001/jama.2020.2648

3. Murthy S, Gomersall CD, Fowler RA. Care for Critically III Patients With COVID-19. JAMA 2020 Mar 11. doi: 10.1001/jama.2020.3633.

4. Ruan Q, Yang K, Wang W, Jiang L, Song J. Clinical predictors of mortality due to COVID-19 based on an analysis of data of 150 patients from Wuhan, China. Intensive Care Med. 2020 May;46(5):846-848. doi: 10.1007/s00134-020-05991-x.

5. Li B, Yang J, Zhao $F$ et al. Prevalence and impact of cardiovascular metabolic diseases on COVID-19 in China. Clin Res Cardiol. 2020 May;109(5):531-538. doi: 10.1007/s00392-020-01626-9

6. Zheng YY, Ma YT, Zhang JY, Xie X. COVID-19 and the cardiovascular system. Nat Rev Cardiol. 2020 May;17(5):259-260. doi: 10.1038/s41569-020-0360-5.

7. Zhou F, Yu T, Du R et al. Clinical course and risk factors for mortality of adult inpatients with COVID-19 in Wuhan, China: a retrospective cohort study. Lancet. 2020 Mar 28;395(10229):1054-1062. doi: 10.1016/S01406736(20)30566-3.

8. Ten Broeke $R$, Mestrom E, Woo L, Kreeftenberg $H$. Early treatment with intravenous lipid emulsion in a potentially lethal hydroxychloroquine intoxication. NethJ Med. 2016;74(5):210. PMID: 27323674

9. Chen $L, L i X$, Chen $M$, Feng $Y$, Xiong $C$. The ACE2 expression in human heart indicates new potential mechanism of heart injury among patients infected with SARS-CoV-2. Cardiovasc Res 2020;116(6):1097-1100. doi: 10.1093/cvr/cvaa078
10. Zhou F, Yu T, Du R et al. Clinical course and risk factors for mortality of adult inpatients with COVID-19 in Wuhan, China: a retrospective cohort study. Lancet 2020;395(10229):1054-1062. doi: 10.1016/S01406736(20)30566-3

11. Fang L, Karakiulakis $G$, Roth M. Are patients with hypertension and diabetes mellitus at increased risk for COVID-19 infection? Lancet Respir Med 2020;8(4):e21. doi: 10.1016/S2213-2600(20)30116-8.

12. Vaduganathan $M$, Vardeny $O$, Michel $T$ et al. ReninAngiotensin-Aldosterone System Inhibitors in Patients with Covid-19. N Engl J Med 2020;382(17):1653-1659. doi: 10.1056/NEJMsr2005760

13. Danser AHJ, Epstein M, Batlle D. Renin-Angiotensin System Blockers and the COVID-19 Pandemic: At Present There Is No Evidence to Abandon Renin-Angiotensin System Blockers. Hypertension 2020;75(6):1382-1385. doi: 10.1161/HYPERTENSIONAHA.120.15082

14. Inciardi RM, Lupi L, Zaccone $G$ et al. Cardiac Involvement in a Patient With Coronavirus Disease 2019 (COVID-19). JAMA Cardiol 2020. doi: 10.1001/ jamacardio.2020.1096

15. Chen C, Zhou Y, Wang DW. SARS-CoV-2: a potential novel etiology of fulminant myocarditis. Herz 2020;45(3):230-232. DOI: 10.1007/s00059-020-04909-z 16. Madjid M, Safavi-Naeini $P$, Solomon SD, Vardeny $O$. Potential Effects of Coronaviruses on the Cardiovascular System: A Review. JAMA Cardiol 2020. doi: 10.1001/jamacardio.2020.1286

17. Sarkisian L, Saaby L, Poulsen TS et al. Clinical Characteristics and Outcomes of Patients with Myocardial Infarction, Myocardial Injury, and Nonelevated Troponins. Am J Med 2016;129:446 e5-446 e21. doi: 10.1016/j.amjmed.2015.11.006

18. Thygesen K, AlpertJS, Jaffe AS et al. Fourth Universal Definition of Myocardial Infarction. Journal of the American College of Cardiology. Volume 72, Issue 18, October 2018. doi: 10.1016/j.jacc.2018.08.1038

19. Yang $X, Y u Y, X u J$ et al. Clinical course and outcomes of critically ill patients with SARS-CoV2 pneumonia in Wuhan, China: a single-centered, retrospective, observational study. Lancet Respir Med 2020; 8(5):475481. doi: 10.1016/S2213-2600(20)30079-5

20. Lippi G, Lavie CJ, Sanchis-Gomar F. Cardiac troponin I in patients with coronavirus disease 2019 (COVID-19): Evidence from a meta-analysis. Prog Cardiovasc Dis. 2020 Mar 10. doi: 10.1016/j.pcad.2020.03.001.

21. Wood S. TCT the Heat Beat: COVID-19 and the Heart: Insights from the Front Lines.

https://www.tctmd.com/news/covid-19-and-heartinsights-front-lines. Accessed March 15, 2020.

22. Kim IC, Kim JY, Kim HA, Han S. COVID-19-related myocarditis in a 21-year-old female patient. Eur Heart J. 2020. May 14;41(19):1859. doi: 10.1093/eurheartj/ ehaa288 
23. Fried JA, Ramasubbu K, Bhatt $R$ et al. The Variety of Cardiovascular Presentations of COVID-19. Circulation. 2020 Jun 9;141(23):1930-1936. doi: 10.1161/ CIRCULATIONAHA. 120.047164

24. Caforio AL, Pankuweit S, Arbustini E et al. European Society of Cardiology Working Group on Myocardial and Pericardial Diseases. Current state of knowledge on aetiology, diagnosis, management, and therapy of myocarditis: a position statement of the European Society of Cardiology Working Group on Myocardial and Pericardial Diseases. Eur Heart J. 2013 Sep;34(33):263648, 2648a-2648d. doi: 10.1093/eurheartj/eht210

25. Lakkireddy DR, Chung MK, Gopinathannair $R$ et al. Guidance for Cardiac Electrophysiology During the Coronavirus (COVID-19) Pandemic from the Heart Rhythm Society COVID-19 Task Force; Electrophysiology Section of the American College of Cardiology; and the Electrocardiography and Arrhythmias Committee of the Council on Clinical Cardiology, American Heart Association. Circulation. 2020 Apr 1;S15475271(20)30289-7. doi: 10.1016/j.hrthm.2020.03.028

26. Chorin E, Dai M, Shulman E, et al. The QT interval in patients with COVID-19 treated with hydroxychloroquine and azithromycin. Nat Med. 2020 Jun;26(6):808-809. doi: 10.1038/s41591-020-0888-2

27. Baldi E, Sechi GM, Mare $C$ et al. Out-of-Hospital Cardiac Arrest during the Covid-19 Outbreak in Italy. N Engl J Med. 2020 Apr 29;NEJMc2010418. doi: 10.1056/NEJMc2010418

28. Hu H, Ma F, Wei X, Fang Y. Coronavirus fulminant myocarditis saved with glucocorticoid and human immunoglobulin. Eur Heart J. 2020 16; ehaa190. doi: 10.1093/eurheartj/ehaa190.
29. Bhatraju PK, Ghassemieh BJ, Nichols M et al. Covid-19 in Critically III Patients in the Seattle Region - Case Series. N Engl J Med. 2020 May 21;382(21):2012-2022. doi: 10.1056/NEJMoa2004500.

30. Lippi G, Lavie CJ, Sanchis-Gomar F. Cardiac troponin I in patients with coronavirus disease 2019 (COVID-19): Evidence from a meta-analysis. Prog Cardiovasc Dis. 2020 doi: 10.1016/j.pcad.2020.03.001

31. Shi S, Qin M, Shen B et al. Association of Cardiac Injury With Mortality in Hospitalized Patients With COVID19 in Wuhan, China. JAMA Cardiol. 2020 Mar 10. doi: 10.1016/j.pcad.2020.03.001.

32. Rotzinger DC, Beigelman-Aubry C, von Garnier $C$, Qanadli SD. Pulmonary embolism in patients with COVID19: Time to change the paradigm of computed tomography. Thromb Res. 2020;190:58-59. doi:10.1016/ j.thromres.2020.04.011

33. Danzi GB, Loffi M, Galeazzi G, Gherbesi E. Acute pulmonary embolism and COVID-19 pneumonia: a random association? Eur Heart J 2020;41(19):1858. doi: 10.1093/eurheartj/ehaa254.

34. Guan WJ, Ni ZY, Hu Y et al. Clinical Characteristics of Coronavirus Disease 2019 in China. N Engl J Med 2020;382(18):1708-1720. doi: 10.1016/j.jinf. 2020.03.041

35. Konstantinides SV, Meyer G, Becattini C et al. 2019 ESC Guidelines for the diagnosis and management of acute pulmonary embolism developed in collaboration with the European Respiratory Society (ERS): The Task Force for the diagnosis and management of acute pulmonary embolism of the European Society of Cardiology (ESC). Eur Respir J 2019;54(3). doi: 10.1183/ 13993003.01647-201 